\title{
Article
}

\section{The Mobile Phone as an Argument for Good Governance in Sub-Saharan Africa}

Asongu, Simplice A, le Roux, Sara, Nwachukwu, Jacinta C and Pyke, Chris

Available at http://clok.uclan.ac.uk/24354/

Asongu, Simplice A, le Roux, Sara, Nwachukwu, Jacinta C ORCID: 0000-00032987-9242 and Pyke, Chris ORCID: 0000-0001-6576-2709 (2019) The Mobile Phone as an Argument for Good Governance in Sub-Saharan Africa.

Information Technology and People, 32 (4). pp. 897-920. ISSN 0959-3845

It is advisable to refer to the publisher's version if you intend to cite from the work. http://dx.doi.org/10.1108/ITP-01-2018-0011

For more information about UCLan's research in this area go to

http://www.uclan.ac.uk/researchgroups/ and search for <name of research Group>.

For information about Research generally at UCLan please go to http://www.uclan.ac.uk/research/

All outputs in CLoK are protected by Intellectual Property Rights law, including Copyright law. Copyright, IPR and Moral Rights for the works on this site are retained by the individual authors and/or other copyright owners. Terms and conditions for use of this material are defined in the policies page.

\section{CLoK}

Central Lancashire online Knowledge www.clok.uclan.ac.uk

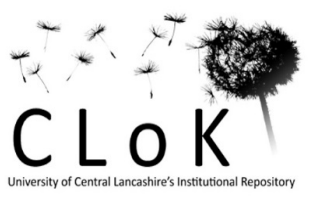


Forthcoming: Information \& Technology People

\author{
Simplice A. Asongu \\ Oxford Brookes University, \\ Faculty of Business; Department of Accounting, \\ Finance and Economics, UK. \\ $\&$ \\ Development Finance Centre, \\ Graduate School of Business, \\ University of Cape Town, Cape Town, South Africa \\ $\&$ \\ Department of Economics \& Development Studies, \\ Covenant University, Ota, Ogun State, Nigeria \\ E-mails: asongusimplice@yahoo.com / \\ asongus@afridev.org \\ Sara le Roux \\ Oxford Brookes University, \\ Faculty of Business; Department of Accounting, \\ Finance and Economics, UK. \\ E-mails: drsaraleroux@gmail.com

\section{Jacinta Nwachukwu} \\ Lancashire School of Business and Enterprise, \\ University of Central Lancashire \\ Preston PR1 2HE \\ United Kingdom \\ Email: jcnwachukwu@uclan.ac.uk

\section{Chris Pyke} \\ Lancashire School of Business and Enterprise, \\ University of Central Lancashire \\ Preston PR1 2HE \\ United Kingdom \\ Email : cpyke2@uclan.ac.uk
}




\title{
The Mobile Phone as an Argument for Good Governance in Sub-Saharan Africa
}

\begin{abstract}
Purpose- This study presents theoretical and empirical arguments for the role of mobile telephony in promoting good governance in 47 sub-Saharan African countries for the period 2000-2012.
\end{abstract}

Design/methodology/approach- The empirical inquiry uses an endogeneity-robust GMM approach with forward orthogonal deviations to analyse the linkage between mobile phone usage and the variation in three broad governance categories - political, economic and institutional.

Findings- Three key findings are established: First, in terms of individual governance indicators, mobile phones consistently stimulated good governance by the same magnitude, with the exception of the effect on the regulation component of economic governance. Second, when indicators are combined, the effect of mobile phones on general governance is three times higher than that on the institutional governance category. Third, countries with lower levels of governance indicators are catching-up with their counterparts with more advanced dynamics.

Originality/value- The study makes both theoretical and empirical contributions by highlighting the importance of various combinations of governance indicators and their responsiveness to mobile phone usage.

JEL Classification: G20; O38; O40; O55; P37

Keywords: comparative study, ICT, IT diffusion and adoption

\section{Acknowledgement}

-The authors are indebted to the editor and reviewers for their constructive comments. 


\section{Introduction}

There are at least five main reasons behind the decision to assess the role of mobile phones $^{1}$ in promoting good governance in sub-Saharan Africa (SSA).

First, while high-end markets in Asia, Europe and North America are experiencing growth stabilisation, African countries still represent substantial growth opportunities in mobiles (Asongu, 2018). This position is consistent with Penard et al. (2012) who had earlier reported that the development of mobile phones versus internet penetration around the world in 2010 has been substantially asymmetric. They noted that while internet and mobile phone penetration rates had reached points of saturation in developed nations, African countries were experiencing an uneven development in the underlying information and communication technologies (ICTs), notably: 9.6 percent for internet penetration and 41 percent for mobile penetration.

Second, a mid-April 2015 World Bank report on the achievement of Millennium Development Goals (MDGs) targets revealed that poverty has been decreasing in all regions of the world with the exception of SSA, with 45 percent of countries in the sub-region offtrack from the MDGs poverty target (World Bank, 2015; Asongu \& Kodila-Tedika, 2017: Bicaba et al., 2017; Asongu et al., 2017). This is despite the sub-region enjoying over two decades of economic growth resurgence that began in the mid-1990s (Fosu, 2015a, p. 44). Moreover, the importance of institutional governance in the exclusive growth of SSA has been the focus of a recent stream of literature, particularly in a book by Fosu (2015b) which investigated the role of institutions in Africa's growth.

Third, in light of the above, the quality of government has been substantially documented to be linked to more inclusive growth, primarily, in: strengthening the basis for societal change (Efobi, 2015) and enhancing living standards through a better management of economic resources (Fosu, 2013a, 2013b; Fonchingong, 2014; Anyanwu \& Erhijakpor, 2014).

Fourth, the inquiry builds on the growing interest for more scholarly research on the development outcomes of mobile phone penetration. Indeed, concern has been raised in some academic circles that the burgeoning phenomenon may simply be considered by some policymakers as a silver bullet for economic development (Mpogole et al., 2008, p. 71; Asongu \& De Moor, 2015) $)^{2}$.

\footnotetext{
1 The terms, 'mobile phone penetration', 'mobile telephony', 'mobiles' and 'mobile phones' are used interchangeably throughout the paper to mean the use mobile phones.

${ }^{2}$ The positioning of the study also departs from recent African literature on the use of information and communication technology for social change, doing business and development (Kuada, 2009; 2014; 2015; Tony
} 
The fifth reason for justifying the current inquiry is that the evolving literature on development externalities of mobile phones has had limited focus on the linkages between mobiles and governance in the sub-continent, in spite of the confirmation of the critical role of institutions in inclusive human development by Fosu, (2015bc). As far as we have reviewed, only four studies have investigated the validity of this proposition in Africa (Snow, 2009; Mathias, 2012; Porter et al., 2015; Gagliardone, 2016). Snow (2009) concluded that there is a negative relationship between the country's rate of mobile penetration and its perceived level of corruption. Mathias (2012) documented a persistent positive impact of mobile connectivity on openness and accountability in Africa. Porter et al. (2015) used data on Ghana, Malawi and South Africa to argue that the increasing mobile phone usage in Africa by the youth in particular, could be tailored towards a more appealing nexus between practice and policy implementation. Gagliardone (2016) evaluated the importance of the interactions between mobile-radio and the quality of government in Africa. The results indicated that preventive and corrective measures are significantly improved by the underlying connections in Kenya.

Noticeably, the above literature leaves room for improvement in at least four areas. First, the need for inquiries with potential for more focused policy implications as opposed to country-specific studies that have limited policy outcomes (Snow, 2009; Porter et al., 2015). Second, while Snow (2009) has exclusively concentrated on corruption, it is important to involve more governance concepts because corruption is only one component of institutional governance. Third, some studies are either not directly focused on employing the mobile phone for better governance (Gagliardone, 2016) or not directly linked to good governance as a policy outcome (Porter et al., 2015). Fourth, while Snow (2009) has established a negative relationship between mobile phones and corruption, the analysis is statistically fragile because it is based on correlations and not causality.

The present study bridges the aforementioned gaps by assessing the effect of mobile phones on ten separate measures of governance in 47 African countries. The empirical evidence is based on an endogeneity-robust Generalised Method of Moments (GMM) with forward orthogonal deviations. For this purpose, we first assess the role of mobile phones in promoting improvements in three broad governance categories. They are: (i) political governance (comprising political stability/no violence and voice \& accountability); (ii) economic governance (involving government effectiveness and regulation quality) and (iii) 2018). 
institutional governance (encompassing corruption-control and the rule of law). We then bundle these individual governance indicators in a robustness check to further investigate how our findings differ when the underlying governance variables are combined into a policy index. Such an empirical approach of bundling and unbundling governance indicators in order to avail room for more policy implications is consistent with recent literature (Asongu \& Nwachukwu, 2016a, 2017).

In order to investigate how the mobile phone usage directly affects selected governance dimensions, we employ the system Generalised Method of Moments estimation technique for five key reasons. They comprise the fact that it (i) supports the continuous structure of our dataset; (ii) accounts for persistence in the governance outcome variables; (iii) retains cross-country variations in the empirical model; (iv) corrects for biases in the difference GMM estimation alternative and (v) adjusts for endogeneity in data. These points are substantiated in the methodology section where we also discuss misspecification problems pertaining to identification and how the GMM restrictions help to correct them.

The remainder of the study is structured as follows. Section 2 clarifies the concept of governance and theoretical underpinnings. Section 3 describes the dataset and methodology. Section 4 presents and explains the empirical results while Section 5 provides concluding remarks with associated policy implications.

\section{Conceptual background and hypotheses development}

\subsection{Conceptual background}

This section will discuss: (i) definitions of governance concepts, (ii) controversial positions on the measurement of governance in the literature, (iii) the justification for bundling and unbundling governance dimensions in mainstream literature and (iv) the concept of mobile (m)-governance.

Consistent with Asongu (2016), many definitions of the concept of governance have been documented in the literature. For brevity, this study adopts the following explanations from papers published in the past decade: According to Dixit (2009), economic governance can be understood as '...structure and functioning of the legal and social institutions that support economic activity and economic transactions by protecting property rights, enforcing contracts, and taking collective action to provide physical and organizational infrastructure ${ }^{3}$ (p.5). Fukuyama (2013), explained that the notion of governance is related to the processes

\footnotetext{
${ }^{3}$ Emphasis on original.
} 
and procedures adopted to enhance the 'state quality' in terms output, politics and production capacity measurements. Tusalem (2015) described governance as a phenomenon that consists of: the rule of law, corruption control, regulation quality and bureaucratic effectiveness. As far as we have reviewed, the most widely used indicators of governance are abstracted from Kaufman, Kraay and Mastruzzi (2010) which according to Andrés et al. (2015) can be classified into three main areas: (i) 'political governance', which is the election and replacement of political leaders. It is measured with voice and accountability and political stability/non-violence; (ii) 'economic governance', which is related to the formulation and implementation of policies that deliver high quality public commodities. It is proxied with regulation quality and government effectiveness; and (iii) 'institutional governance' which is defined as the respect of the State and citizens of institutions that govern interactions between them. It is measured by the extent of deference for the rule of law and corruption-control.

The above mentioned governance indicators from Kaufmann et al (2010) have been criticized by a number of authors. The most thought-provoking condemnations have been from Kurtz and Schrank (2007a and b) who appraised the models, measures and mechanisms employed by Kaufmann et al(2010). Their critique resulted in a to-and-fro debate as follows: To begin with, Kurtz and Schrank (2007a) questioned the premise under which governance is positively linked to economic development by Kaufman et al. They presented a case for reexamining the over-confidence that the indicators from Kaufman et al are enjoying in mainstream literature. They concluded that the underpinning indicators of governance are marred by a number of concerns, among others: perceptual biases, conceptual conflation with policy choices and sampling adverse selection. In reply to these allegations, Kaufmann et al (2007a) provided empirical evidence to demonstrate that the (i) criticisms from antagonistic authors on 'perception-based measurement biases' in their governance indicators are speculative, falsifiable and do not withstand empirical scrutiny; (ii) short-run nexus between governance and growth purported by the other protagonists is conceptually flawed and (iii) findings of empirical studies by the contenders on the economic growth-governance relationship are not robust to specific conditions in these countries. Kurtz and Schrank (2007b) defended their appraisal on the basis that their initial concerns on measurement and conceptual opaqueness significantly build on the debate surrrounding the growth-governance nexus. According to these authors, underlying anxieties about 'potential respondant bias' are not entirely limited to the measurement of government effectivess, but could be extended to other variables. Kaufmann et al (2007b) further provided a rejoinder in a second reply where 
they reiterated the lack of empirical justification for the criticisms advanced by Kurtz and Schrank.

In this paper we adopt the Kaufmann et al (2007a, 2007b, 2010) governance indicators, primarily because of data availability and because to the best of our knwoledge, they are the most widely used governance measurements in the literature. As noted in the introduction, in order to provide robust findings while demonstrating the opportunities for further policy implications, we bundle our selected individual governance indicators into four indices representing: (i) political governance, (ii) economic governance, (iii) institutional govenance and (iv) general governance. The technique of bundling and unbundling governance indicators is consistent with a stream of African institutional literature. They include articles on revolution empirics in the prediction of the Arab Spring by Asongu \& Nwachukwu (2016b); the role of instutitions in knowledge economy in Africa by Andrés et al (2015); governance mechanisms in the fight against software piracy by Andrés \& Asongu, (2013) and crimes/conflicts by Asongu \& Kodila-Tedika (2016) in Africa and economic governnce as the most important determinants of innovation in Africa by Oluwatobi et al (2015).

Finally, the concept of e-governance is clarified by Hellstrom (2008). The author suggests the phenomenon could be understood as the employment of the various types of ICTs for enhancing rewards to parties involved in electronic (e)-governance. The parties include businesses, citizens and government units. According to the author, the use of mobile phone applications to encourage good governance consists of employing the mobile technology to among others, improve public service delivery, citizenary participation and respect of instituions within the State.

\subsection{Theoretical insights and hypotheses development}

It is important to note that, to the best of our knowledge, no theoretical model has been developed on the relationship between mobile phone usage and governance. This is the reason why the term "argument" is explicitly added to the title of this paper. Therefore, beyond theoretical foundations, providing an empirical insight into new phenomena like mobile phone-governance interconnections is important for motivating future theory-building exercises. Indeed, Costantini and Lupi, (2005) and Narayan et al., (2011) affirmed that an empirical exercise based on sound intuition is a useful scientific activity because "applied econometrics" is not exclusively based on the acceptance or rejection of existing theories. 
Additionally, Hellstrom (2008) remarked that ICTs can be used to improve governance dimensions, primarily because they promote transparency, oppeness and quasifree flow of information between institutions and governmnt ministries. According to the narrative, the mobile phone has the potential of facilitaing (i) the free flow of information between citizens and the government and (ii) direct participation of citizens in influencing decisions that govern them.This involvement is possible through protests organised and coordinated with the help of mobile phones or through direct communication with government officials with mobile phones. In a nutshell, mobile phones enable converging societies that are more connected, participative and informative.

Snow (2009, pp. 337-339) has provided theoretical concepts on the potential role of mobiles in government effectiveness. The theory maintains that the historic dearth of ICT in Africa enabled the elite to enjoy preferential communication and information services. These conditions seriously constrained accountability and transparency, hence providing an enabling environment for corruption among the ruling classes. To this end, the author postulated that the net impact of the rapid diffusion of mobile phones in Africa is very likely to be a reduction in corruption, especially among the ruling elite. It follows that such liberlisation in ICT would shed light on the barriers that hitherto shielded corrupt elites, prevented oversight with related punishment as well as altered the results of cost-benefits calculations of public sector investments. It is important to note that the theory popularised by Snow (2009) focused exclusively on the corruption aspect of institutional governance. We adopt the key ideas of Snow (2009) to substantiate the three propositions investigated in this study. We hypothesize a positive relationship between mobile phones and the development in the three major dimensions of governance employed in the current study, namely political governance, economic governance and institutional governance.

The mechanisms by which mobile phone promotes good political governance are: "voice \& accountability" and "political stability". From the perspective of "voice \& accountability", mobile phones can be used to coordinate the organisation of peaceful protests aimed at compelling government officials to be truthful and answerable to their citizens. In the same vein, the mobile phone can be used to highlight the extent to which a country's citizens are able to participate in selecting their government and enjoy freedom of expression and 
membership of different political parties. ${ }^{4}$ Concerning the view of "political stability", we propose that the rewards of mobile phone penetration in limiting violence at civil protests, political rallies and abuse of power by officials, including the Police and the Army outweigh the criticism that mobile phones could be used to incite civil rebellion and fuel terrorism. This is probably because citizens are increasingly aware of the medium and long term economic hardships associated with a destabilisation or overthrow of an elected government by unconstitutional means, including coup-d'etat, terrorism and domestic violence.

Hypothesis 1: Mobile phone usage influences good political governance by facilitating a free and fair election and replacement of political leaders.

The mechanisms by which mobile phone usage promotes economic governance are: government effectiveness and regulation quality. Logically, the expedition and simplification of communication between government departments as well as between government officials and citizens is essential for greater participation in the design and implementation of economic policies.

Hypothesis 2: Mobile phones influence economic governance by expediting the formulation and implementation of policies that deliver better public services.

Channels through which such institutional governance is improved are corruption-control and adherence to the rule of law. The intuition supporting this third dimension of our proposition is broadly consistent with the theoretical underpining of Snow (2009) which we described in previous paragraphs. As a summary of the narrative, ICT has increased transparency, reduced corruption and facilitated respect of the rule of law because it has substantially decreased the monopoly of preferential communication and information services by a few ruling elite.

\footnotetext{
${ }^{4}$ It is important to note that this manuscript is positioned as an argument. Hence, it is worthwhile to balance the narrative with potential counter arguments that can arise from scholarly and policy circles. It may also be argued that government selection is by universal suffrage and that voting is not done by means of mobile phones. However, the mobile phone can help to facilitate universal suffrage through coordination and communication. It is also relevant to mention that, mere possession of a mobile phone does not imply that there is freedom of expression. In some countries (e.g., China), the mobile penetration rate is high but still the government is criticized of deprivation of human rights.
} 
Hypothesis 3: The use of the mobile phones affect institutional governance by enabling the citizens and the State to respect insitutions that govern interactions between them.

Generally speaking, we argue that, our hypotheses are consistent with the theory by Snow (2009) in the sense that information capture by the ruling elite is a potential source of corruption and poor governance metrics (political, economic and institutional). Hence, information decentralisation by means of the mobile telephony reduces opportunities for depraved institutional practices to take root. These suggestions with associated theoretical underpinnings are in conformity with the bulk of literature on the relationhip between ICTs and governance (Suarez, 2006; Boulianne, 2009; Diamond, 2010; Grossman et al., 2014).

Nevertheless, it is important to balance the theoretical concepts with the stream of literature insinuating that ICTs can facilitate violent collective action (Breuer et al., 2012; Pierskalla \& Hollenbach, 2013; Weidmann \& Shapiro, 2015; Manacorda \& Tesei, 2016). It is also useful to modify our narrative with some discussion on channels through which mobile phones might actually reduce the quality of government. For example, Morozov (2011) noted that the use of ICTs by the incumbent government for propaganda is an important connection between ICTs and poor governance. Other factors influencing the ICT-poor governance relationship may include the extra costs arising from the use of mobile phones to obtain the information needed to hold the ruling classes to account for their actions, demand for reforms in individual economic empowerment and organise civil protests and political rallies.

Sections 1 and 2 have focused on the mobile phone-governance context in SubSaharan Africa in the sense that the argument motivates the present study. However, it is also pertinent to elucidate how this logic could be expanded to other regions of the world characterised by lower levels of mobile phone penetration and poor governance. The extension does not imply that the mobile phone will equally improve all dimensions of governance under consideration in these further regions. This is essentially because the economic development paradigms of countries differ. For instance, a country can prioritise political governance while others put emphasis on economic governance in their development plan. Examples with which to illustrate this point are the two dominant models of economic development in the world, namely: the Washington Consensus and the Beijing Model. According to recent literature (Asongu \& Ssozi, 2016), the Washington Consensus can be defined as "liberal democracy, private capitalism and priority in political rights" while the Beijing Model can be defined as "de-emphasised democracy, state capitalism and priority in 
economic rights". Within the context of this study (i.e. the definitions provided in Section 2.1), political rights are consistent with political governance whereas economic rights are in line with economic governance dynamics.

Even within a given dimension of governance such as political governance (i.e. consisting of political stability and "voice and accountability"), priorities of the two dominant models may still differ. For instance, China which promotes the Beijing Model enjoys better political stability than most African countries which are largely following the prescriptions of the Washington Consensus that emphasises the relevance of "voice and accountability" in political governance. Nevertheless, we propose that the framework underlying this study can be extended to countries with development paradigms and dynamics of governance comparable with those in the sub-Saharan African economies. ${ }^{5}$.

\section{Data and Methodology}

\subsection{Data}

The study investigates a panel of 47 countries in SSA with data from African Development Indicators of the World Bank for the period 2000-2012. Of the 49 existing countries in SSA, South Sudan and Somalia are excluded from the sample because of data availability constraints. In line with the discourse in Section 2, six individual governance indicators from Kaufmann et al. (2010) are used as dependent variables in the main regression specifications and four additional governance indices, bundled by principal component analysis (PCA) are used for robustness checks. The six individual governance indicators comprise: (i) voice and accountability; and (ii) political stability/no violence (which proxy political governance); (iii) government effectiveness and (iv) regulation quality (which measure economic governance); (v) corruption-control and (vi) the rule of law (which captures institutional governance). These indicators have been widely used in governance empirical studies in the past ten years (see for example Gani, 2011; Andrés et al., 2015; Yerrabit \& Hawkes, 2015; Ajide \& Raheem, 2016a, 2016b).

The independent variable of interest i.e., the mobile technology variable is proxied by the mobile phone penetration rate (per 100 people). This decision is consistent with recent knowledge economy literature (Tchamyou, 2017).

\footnotetext{
${ }^{5}$ Asongu and le Roux (2018) have recently built on these governance dynamics and the two dominant models to explain Africa's extreme poverty tragedy.
} 
The selected control variables are: (i) economic growth, (ii) population growth, (iii) foreign direct investment (FDI) and (iv) foreign aid. The choice of these control variables is informed by discussion in the literature. For example, the variables for economic growth and population growth were recently used to control the movement of governance dynamics in the prediction of the Arab Spring (Asongu \& Nwachukwu, 2016b). We expect a positive relationship between these variables and our choice of governance metrics because while higher income-levels are associated with better governance ethics, more resources are expected to be allocated for improving governance standards with growing population. This optimistic narrative should be mitigated by the fact that a substantial increase in the number of inhabitants may also infringe on the ability of a government to effectively manage the demands of a rising population. Financial globalisation has been confirmed to raise governance standards in developing countries (Lalountas et al., 2011). By contrast, the effect of foreign aid may either be positive or negative in light of the conflicting literature on the relationship between foreign aid and governance in Africa (Okada \& Samreth, 2012; Asongu \& Nwachukwu, 2016c). For instance, whereas Okada and Samreth (2012) found that foreign aid reduced corruption in developing countries, Asongu and Nwachukwu, (2016c) concluded that foreign aid undermined governance principles in recipient Africa countries. However, we expect the sign in our current analysis to be negative in line with the Asongu and Nwachukwu study because this study focused exclusively on African economies and also uses all the six individual governance indicators employed in the current inquiry.

The definition and sources of variables are disclosed in Appendix 1, while the corresponding summary statistics are provided in Appendix 2. The correlation matrix is presented in Appendix 3.

The summary statistics show that the Means of the variables are comparable and in the light of corresponding variations, we can be confident that reasonable expected relationships with our selected governance dimensions would emerge. The primary purpose of the correlation matrix is to inform on potential issues of multicollinearity. We notice that concerns about degrees of substitution among variables are apparent among governance variables. However, consistent with the narrative in Section 2 on the need to bundle and unbundle governance indicators, conceptual priority takes precedence over degrees of substitution. The concern about multicollinearity is not of a nature to bias estimated coefficients because the governance indicators are used as dependent variables in distinct specifications. 
It is important to clarify that some governance indicators have figures that exceed the standardised range of -2.5 to +2.5 , notably: non principal component (PC)-augmented variables and PC-augmented variables. With regard to PC-augmented variables, contingent on eigenvalues and percentage of variation corresponding to the retained first PC, variables from PCs can have ranges that are higher than those apparent in their constituent components. Hence, -4.049 corresponding to a PC-augmented variable is not a cause for concern. With regard to non PC-augmented variables, some negative political stability observations for Sudan exceed the lower limit of -2.5. Fortunately, this does not affect the findings because the observations are very close to the lower limit and occur exclusively in three out of our twelve years of study - 2009, 2010 and 2011.

\subsection{Estimation technique}

\subsubsection{Specification}

The study uses a GMM approach for five main reasons. First, the procedure of estimation is a good fit because of the presence of persistent dependent variables. As observed in Appendix 4, the rule of thumb requirement for evidence of persistence (0.800) is apparent because the lowest correlation coefficient between governance variables and their corresponding lagged values is 0.965 . Second, the number of countries $(\mathrm{N})$ is higher than the number of years per country in a given time series (T). Hence, the $\mathrm{N}(47)>\mathrm{T}(12)$ condition for the application of the GMM technique is satisfied. Third, the approach does not eliminate cross-country variations. Fourth, the estimation technique corrects for endogeneity in all regressors, primarily by controlling for time invariant omitted variables. Fifth, consistent with Bond et al. (2001, pp. 3-4), the system GMM estimator (Arellano \& Bover, 1995; Blundell \& Bond, 1998) is preferred to the difference estimator (Arellano \& Bond, 1991). According to Asongu and De Moor (2016), the first-two are requirements for adopting the approach while the last-three are rewards linked to using the estimation strategy.

The current inquiry is an extension of Arellano and Bover (1995) based on forward orthogonal deviations technique suggested by Roodman (2009ab). The key properties of the resulting GMM- estimation method with forward orthogonal deviations have been documented by Love and Zicchino (2006) and Baltagi (2008). They include its ability to restrict over-identification and/or limit instrument proliferation. In these previous studies, a two-step approach is preferred to the one-step because it accurately accounts for heteroscedasticity. In essence, the one-step technique is homoscedasticity-consistent. In 
principle, we do not need any test for heteroscedasticity to justify the two-step approach because; the assumption of homoscedasticity (or homogeneity of variance) is less realistic than the assumption of heteroscedasticity (or heterogeneity of variance).

The following equations in levels (1) and first difference (2) summarise the standard system GMM estimation procedure.

$$
\begin{aligned}
G_{i, t}=\sigma_{0}+ & \sigma_{1} G_{i, t-\tau}+\sigma_{2} M_{i, t}+\sum_{h=1}^{4} \delta_{h} W_{h, i, t-\tau}+\eta_{i}+\xi_{t}+\varepsilon_{i, t} \\
G_{i, t}-G_{i, t-\tau}= & \sigma_{1}\left(G_{i, t-\tau}-G_{i, t-2 \tau}\right)+\sigma_{2}\left(M_{i, t}-M_{i, t-\tau}\right) \\
& +\sum_{h=1}^{4} \delta_{h}\left(W_{h, i, t-\tau}-W_{h, i, t-2 \tau}\right)+\left(\xi_{t}-\xi_{t-\tau}\right)+\left(\varepsilon_{i, t}-\varepsilon_{i, t-\tau}\right)
\end{aligned}
$$

where $G_{i, t}$ is a governance indicator (political, economic or institutional governance) of country $i$ at period $t ; \sigma_{0}$ is a constant; $\tau$ represents the coefficient of autoregression; $M$, Mobile phone penetration; $W$ is the vector of control variables (GDP growth, population growth, foreign investment, and foreign aid), $\eta_{i}$ is the country-specific effect, $\xi_{t}$ is the timespecific constant and $\varepsilon_{i, t}$ is the error term.

It is necessary to test for stationarity in the variables. The unit root tests overwhelmingly show that the variables are stationary. The unit root tests are based on ImPesaran-Shin and Fisher types because the Breitung and Levin-Lin and Chu tests require a balanced panel dataset (see Tchamyou et al., 2018; Tchamyou, 2018a) ${ }^{6}$.

\subsubsection{Identification simultaneity and exclusion restrictions}

In accordance with recent literature (see Dewan \& Ramaprasad, 2014; Asongu \& De Moor, 2017; Tchamyou, 2018b; Boateng et al., 2018), all independent variables are considered as either predetermined or potentially endogenous. Within this framework, the method for treating them is the gmmstyle. Time-invariant omitted variables are treated as strictly exogenous and the procedure for treating the corresponding ivstyle (years) is 'iv(years, eq(diff))'. This is specifically because it is very unlikely for time-invariant omitted variables to become endogenous after first-difference (see Roodman, 2009b). In the light of the identification process, all independent variables are potentially endogenous. The concern of endogeneity is addressed in two ways. First, we control for time effects in order to account

\footnotetext{
${ }^{6}$ Due to space constraint, the results of our panel unit root tests are not presented here, but are available from the lead author on request.
} 
for errors associated with the unobserved heterogeneity, simultaneity and reverse causality. Second, we use lagged variables as instruments for variables that are forward-differenced.

Theoretically, fixed effects which are expected to affect the estimated relationships are eliminated by employing Helmet transformations on the regressors (see Arellano \& Bover, 1995; Love \& Zicchino, 2006). The conversion consists of employing forward meandifferencing of the indicators. This means that all future observations are subtracted from the lagged indicators, instead of deducting past observations from contemporary ones. Such an alteration enables parallel or orthogonal conditions between the forward-differenced indicators and lagged values. Irrespective of the number of lags, in order to avoid the loss of data, the underlying transformations are performed for all observations, except for the last observation for each country, "and because lagged observations do not enter the formula, they are valid as instruments" (see Roodman, 2009b, p. 104; Asongu \& De Moor, 2017).

With respect to exclusion restrictions, time-invariant omitted indicators that are considered as strictly exogenous affect governance variables exclusively through the suspected endogenous indicators. The validity of the exclusion restriction is investigated with the Difference in Hansen Test (DHT) for the exogeneity of instruments. Accordingly, in order for the dependent variable to be fully explained by time-invariant omitted indicators through the potential endogenous mechanisms, the null hypothesis for the DHT should not be rejected. Hence, the DHT procedure is used to examine if time-invariant omitted indicators exhibit strict exogeneity by explaining governance measurements solely through the endogenous channels or variables. Therefore, in the results that are reported in the following section, the validity of the exclusion restriction is confirmed if the null hypotheses of DHT corresponding to IV (year, eq(diff)) are not rejected.

\section{Empirical results}

\subsection{Presentation of results}

Consistent with Tchamyou and Asongu (2017), the study uses the following information criteria to assess the validity of models: First, the alternative hypothesis of the second-order Arellano and Bond autocorrelation test $(\mathrm{AR}(2))$ in difference which informs on whether the presence of autocorrelation in the residuals should be rejected. Second, a check on the validity of instruments is based on the alternative hypotheses of the Sargan and Hansen over-identification restrictions (OIR) tests. Their null hypotheses are that the instruments are valid and not correlated with the error terms. Accordingly, the Hansen (Sargan) OIR test is 
robust (resp. not robust) but weakened (resp not weakened) by instruments. It is specifically for the interest of limiting instrument proliferation that specifications have been tailored to meet the rule of thumb requirement that restricts over-identification, notably: the instruments are lower than the number of countries in every specification. Third, in order to ascertain the validity of Hansen OIR results, the OIR tests are further examined with the Difference in Hansen Test (DHT) for exogeneity of instruments. Fourth, we also provide a Fisher test that assesses the joint validity of estimated coefficients.

The following three findings can be confirmed from Table 1. First, mobile phones consistently promote good governance by the same magnitude, with the exception of regulation quality for which the effect is nearly doubled. Unfortunately, the effect on regulation quality is not feasible because of the absence of autocorrelation in the residuals. Second, there is some degree of convergence in governance metrics given that the absolute value of the coefficients on the lagged endogenous variable is between 0 and $1^{7}$. In summary all the three hypotheses investigated in this paper are valid because the mobile phone has positive effects on political governance, economic governance and institutional governance. Third, most of the significant control variables have the expected signs.

\footnotetext{
${ }^{7}$ The interested reader can find more insights into the computation of the implied rate of convergence in Asongu (2014).
} 
Table 1: The mobile phone and governance standards

Dependent variable: governance indicators

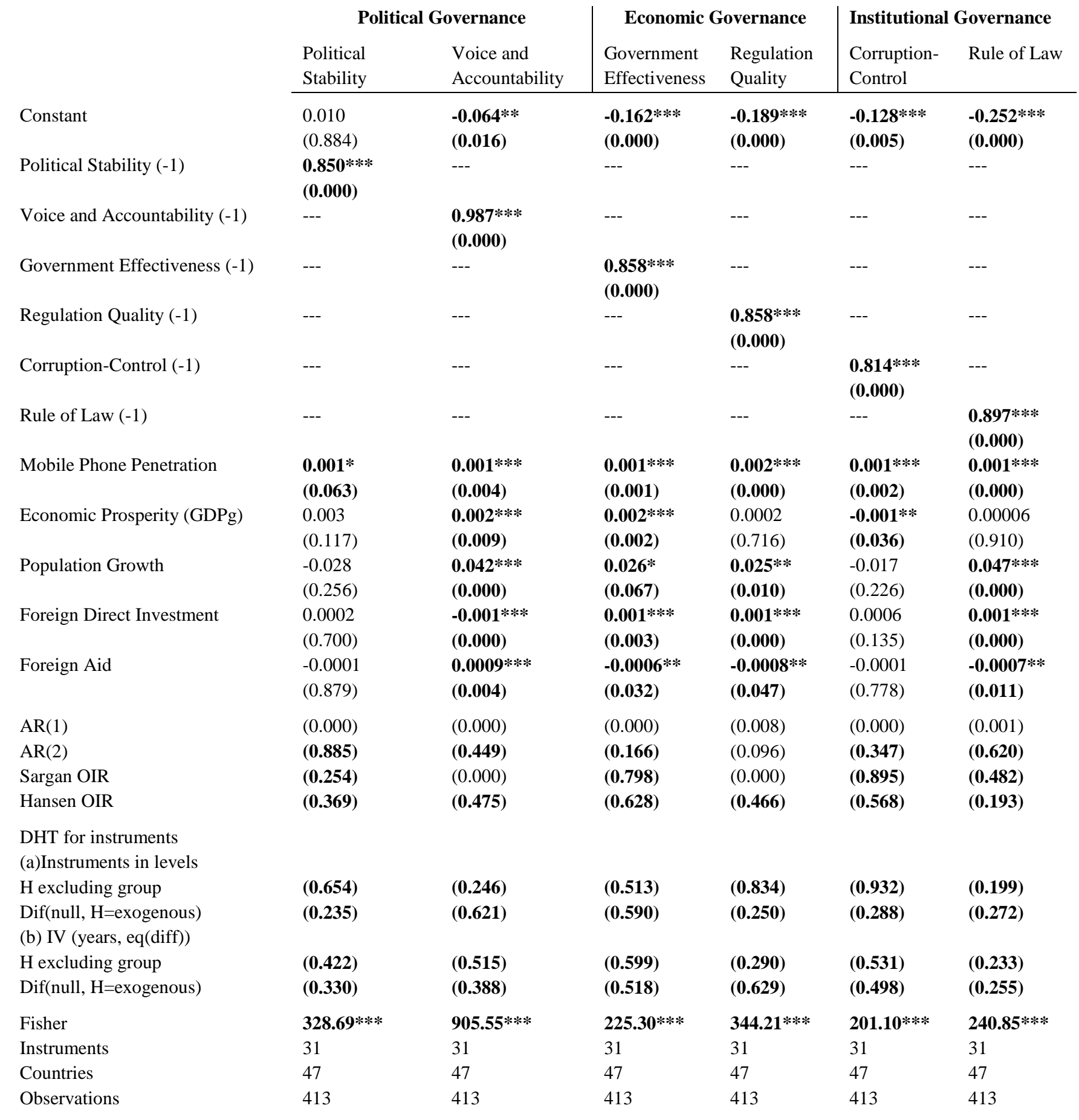

*,**,***: significance levels of 10\%, 5\% and 1\% respectively. DHT: Difference in Hansen Test for Exogeneity of Instruments' Subsets. Dif: Difference. OIR: Over-identifying Restrictions Test. The significance of bold values is twofold. 1) The significance of estimated coefficients and the Fisher statistics. 2) The failure to reject the null hypotheses of: a) no autocorrelation in the AR(1) and AR(2) tests and; b) the validity of the instruments in the Sargan OIR test. The numbers in parentheses are p-values. There is a difference between the total number of observations in the regression output and the total number of observations disclosed in the summary statistics is because of concerns about missing observations. The GMM strategy eliminates missing observations because lagged variables are used as instruments. (-1) stands for the lagged dependent variable. 


\subsection{Robustness checks}

We employ principal component analysis (PCA) to bundle the individual governance indicators into four indices, namely: political, economic, institutional and general governances. The procedure has been employed in recent African governance literature by Asongu and Nwachukwu (2016b). PCA is a statistical technique that is often employed to reduce a large set of correlated indicators into a small set of uncorrelated variables called principal components (PCs) which represent most of the variation in the original dataset. Consequently, we condense the six individual governance measures to one common factor general governance. Therefore, the estimated general governance variable is a composite index consisting of the following six dynamics: (i) political stability, (ii) voice and accountability, (iii) government effectiveness, (iv) regulation quality, (v) rule of law and (vi) corruption-control.

We use the Kaiser (1974) and Jolliffe (2002) criterion to retain common factors. Both authors recommended that only PCs which have an eigenvalue that is greater than the Mean or one should be kept. For instance, in Table 2, it can be observed that first PC in the General governance model (G.Gov) has an eigenvalue of 4.892 and accounts for more than 81 percent of variations in the six constituent variables. Similarly, the first principal components for political governance (Polgov), economic governance (Econgov) and institutional governance (Instgov) have eigenvalues (total variations) of 1.671, 1.878 and 1.861(83.5 percent, 93.9 percent and 93.0 percent) respectively.

As documented by Asongu and Nwachukwu (2016b), a number of issues may arise when variables that are derived from other regressions are employed in further empirical modelling. They noted that problems relating to efficiency, consistency and validity of inferences were first documented by Pagan (1984, p. 242). Pagan recognised that whereas two-step estimators are consistent and efficient, few provide valid inferences. The narrative is in accordance with a broad stream of studies on the subject, notably: Oxley and McAleer (1993), McKenzie and McAleer (1997), Ba and Ng (2006) and Westerlund and Urbain (2013a). 
Table 2: Principal Component Analysis (PCA) for Governance (Gov)

\begin{tabular}{|c|c|c|c|c|c|c|c|c|c|}
\hline $\begin{array}{c}\text { Principal } \\
\text { Components }\end{array}$ & \multicolumn{6}{|c|}{ Component Matrix (Loadings) } & Proportion & \multirow{2}{*}{$\begin{array}{l}\text { Cumulative } \\
\text { Proportion }\end{array}$} & $\begin{array}{l}\text { Eigen } \\
\text { Value }\end{array}$ \\
\hline & VA & PS & RQ & GE & $\mathbf{R L}$ & $\mathrm{CC}$ & & & \\
\hline First PC (G.Gov) & 0.395 & 0.372 & 0.411 & 0.426 & 0.439 & 0.404 & 0.815 & 0.815 & 4.892 \\
\hline Second PC & -0.037 & 0.873 & -0.357 & -0.303 & 0.037 & -0.124 & 0.067 & 0.883 & 0.407 \\
\hline Third PC & 0.747 & -0.035 & 0.157 & -0.131 & -0.086 & -0.626 & 0.052 & 0.935 & 0.314 \\
\hline First PC (Polgov) & 0.707 & 0.707 & --- & -- & --- & --- & 0.835 & 0.835 & 1.671 \\
\hline Second PC & -0.707 & 0.707 & --- & --- & --- & --- & 0.164 & 1.000 & 0.328 \\
\hline $\begin{array}{l}\text { First PC } \\
\text { (Econgov) }\end{array}$ & --- & --- & 0.707 & 0.707 & --- & --- & 0.939 & 0.939 & 1.878 \\
\hline Second PC & --- & --- & -0.707 & 0.707 & --- & --- & 0.060 & 1.000 & 0.121 \\
\hline First PC (Instgov) & --- & --- & --- & --- & 0.707 & 0.707 & 0.930 & 0.930 & 1.861 \\
\hline Second PC & --- & --- & --- & --- & -0.707 & 0.707 & 0.069 & 1.000 & 0.138 \\
\hline
\end{tabular}

P.C: Principal Component. VA: Voice \& Accountability. RL: Rule of Law. R.Q: Regulation Quality. GE: Government Effectiveness. PS: Political Stability. CC: Control of Corruption. G.Gov (General Governance): First PC of VA, PS, RQ, GE, RL \& CC. Polgov (Political Governance): First PC of VA \& PS. Econgov (Economic Governance): First PC of RQ \& GE. Instgov (Institutional Governance): First PC of RL \& CC.

Reflecting the underlying concern on the use of PC derived governance variables in the context of this inquiry, Westerlund and Urbain $(2012,2013 b)$ have built on previous studies (Pesaran, 2006; Stock \& Watson, 2002; Bai, 2003; Bai, 2009; Greenaway-McGrevy et al., 2012) to confirm that normal inferences are possible with PC-factor augmented regressions if estimated coefficients converge to their true values at the rate $\sqrt{N T}$, (with $\mathrm{T}$ being the number of time series and $\mathrm{N}$ denoting cross-section observations). While the authors have suggested that $\mathrm{N}$ and $\mathrm{T}$ should be sufficiently large for this convergence to be feasible, they have stopped short of eliciting how 'large is large'. Within the framework of this study, we are confronted with two major problems. First, we cannot increase $\mathrm{N}$ further because we have engaged all existing 47 countries in SSA with adequate data on our key variables governance and mobile phone penetration rate. Second, extending $\mathrm{T}$ further could result in instrument proliferation that might bias estimated results. Asongu and Nwachukwu (2016b) confirmed using the same governance variables (albeit with lower $\mathrm{N}$ and $\mathrm{T}$ ) that inferences are not substantially different, irrespective of whether bundled and unbundled governance indicators are used. They discussed some of the estimation issues surrounding the validity of PC-augmented (or derived) variables, including the use of GMM technique.

Table 3 provides the results of our robustness check based on the bundled governance indices. Three major findings are uncovered. First, with the exception of political governance for which the effect of the mobile phone is not significant and the economic governance model which is not valid, corresponding impacts on the other governance indicators are positive. The magnitude of the impact on general governance is three times as high as that on 
institutional governance. Second, based on the lagged endogenous variables, while the influence corresponding to political governance is not stationary, the effects of other governance indicators are static in the sense that the estimated coefficients are less than one.

Third, most of the significant control variables have expected signs.

Table 3: The mobile phone and bundled governance indices

\begin{tabular}{|c|c|c|c|c|}
\hline & \multicolumn{4}{|c|}{ Dependent variable: Governance indices } \\
\hline & Political Governance & $\begin{array}{l}\text { Economic } \\
\text { Governance }\end{array}$ & $\begin{array}{l}\text { Institutional } \\
\text { Governance }\end{array}$ & $\begin{array}{l}\text { General } \\
\text { Governance }\end{array}$ \\
\hline Constant & $\begin{array}{l}-\mathbf{0 . 0 8 6 *} \\
(0.067)\end{array}$ & $\begin{array}{l}-0.197 * * * \\
(0.003)\end{array}$ & $\begin{array}{l}-0.219 * * * \\
(0.002)\end{array}$ & $\begin{array}{l}-0.224 * * * \\
(0.006)\end{array}$ \\
\hline Political Governance $(-1)$ & $\begin{array}{l}1.010 * * * \\
(0.000)\end{array}$ & --- & --- & --- \\
\hline Economic Governance $(-1)$ & --- & $\begin{array}{l}0.876 * * * \\
(0.00)\end{array}$ & --- & --- \\
\hline Institutional Governance $(-1)$ & --- & --- & $\begin{array}{l}0.910 * * * \\
(0.000)\end{array}$ & --- \\
\hline General Governance $(-1)$ & --- & --- & --- & $\begin{array}{l}0.942 * * * \\
(0.000)\end{array}$ \\
\hline Mobile Phone Penetration & $\begin{array}{l}0.0001 \\
(0.849)\end{array}$ & $\begin{array}{l}\mathbf{0 . 0 0 3 * * *} \\
(\mathbf{0 . 0 0 0 )}\end{array}$ & $\begin{array}{l}\mathbf{0 . 0 0 1} * * \\
(\mathbf{0 . 0 2 0})\end{array}$ & $\begin{array}{l}\mathbf{0 . 0 0 3} * * * \\
(0.000)\end{array}$ \\
\hline Economic Prosperity (GDPg) & $\begin{array}{l}0.003 \\
(0.153)\end{array}$ & $\begin{array}{l}0.001 \\
(0.191)\end{array}$ & $\begin{array}{l}-0.002 * * \\
(0.015)\end{array}$ & $\begin{array}{l}\text { 0.002* } \\
(0.082)\end{array}$ \\
\hline Population Growth & $\begin{array}{l}0.019 \\
(0.306)\end{array}$ & $\begin{array}{l}0.071 * * * \\
(0.002)\end{array}$ & $\begin{array}{l}\mathbf{0 . 0 5 6} * * \\
(\mathbf{0 . 0 1 4})\end{array}$ & $\begin{array}{l}\mathbf{0 . 0 8 5 * * *} \\
(\mathbf{0 . 0 0 6 )}\end{array}$ \\
\hline Foreign Direct Investment & $\begin{array}{l}-\mathbf{0 . 0 0 1 * * * *} \\
(0.009)\end{array}$ & $\begin{array}{l}\mathbf{0 . 0 0 3 * * *} \\
(\mathbf{0 . 0 0 0 )}\end{array}$ & $\begin{array}{l}0.001 * * \\
(0.011)\end{array}$ & $\begin{array}{l}0.0003 \\
(0.635)\end{array}$ \\
\hline Foreign Aid & $\begin{array}{l}0.002 * * * \\
(0.000)\end{array}$ & $\begin{array}{l}-0.001 * * \\
(0.032)\end{array}$ & $\begin{array}{l}-0.0009 \\
(0.142)\end{array}$ & $\begin{array}{l}-0.108 * \\
(0.061)\end{array}$ \\
\hline $\begin{array}{l}\text { AR(1) } \\
\text { AR(2) } \\
\text { Sargan OIR } \\
\text { Hansen OIR }\end{array}$ & $\begin{array}{l}(0.001) \\
(\mathbf{0 . 6 1 6}) \\
(0.045) \\
(\mathbf{0 . 6 6 7 )}\end{array}$ & $\begin{array}{l}(0.000) \\
(0.032) \\
(\mathbf{0 . 2 3 7}) \\
(\mathbf{0 . 5 7 8})\end{array}$ & $\begin{array}{l}(0.000) \\
(\mathbf{0 . 1 5 0 )} \\
(\mathbf{0 . 9 6 2 )} \\
(\mathbf{0 . 7 1 3 )}\end{array}$ & $\begin{array}{l}(0.000) \\
(\mathbf{0 . 1 9 8 )} \\
(\mathbf{0 . 9 6 0 )} \\
(\mathbf{0 . 6 3 7 )}\end{array}$ \\
\hline $\begin{array}{l}\text { DHT for instruments } \\
\text { (a)Instruments in levels }\end{array}$ & & & & \\
\hline H excluding group & $(0.816)$ & $(0.559)$ & $(0.584)$ & $(\mathbf{0 . 3 8 5})$ \\
\hline $\begin{array}{l}\text { Dif(null, H=exogenous) } \\
\text { (b) IV (years, eq(diff)) }\end{array}$ & $(\mathbf{0 . 4 5 7})$ & $(0.500)$ & $(0.652)$ & $(0.693)$ \\
\hline H excluding group & $(0.599)$ & $(0.302)$ & $(\mathbf{0 . 8 3 3 )}$ & $(\mathbf{0 . 8 7 3 )}$ \\
\hline Dif(null, $\mathrm{H=exogenous)}$ & $(0.576)$ & $(0.781)$ & $(0.417)$ & $(0.289)$ \\
\hline Fisher & $671.83 * * *$ & 413.52*** & $205.90 * * *$ & $806.32 * * *$ \\
\hline Instruments & 31 & 31 & 31 & 31 \\
\hline Countries & 47 & 47 & 47 & 47 \\
\hline Observations & 413 & 413 & 413 & 413 \\
\hline
\end{tabular}

*,**,***: significance levels of $10 \%, 5 \%$ and $1 \%$ respectively. DHT: Difference in Hansen Test for Exogeneity of Instruments' Subsets. Dif: Difference. OIR: Over-identifying Restrictions Test. The significance of bold values is twofold. 1) The significance of estimated coefficients, Hausman test and the Fisher statistics. 2) The failure to reject the null hypotheses of: a) no autocorrelation in the AR(1) and AR(2) tests and; b) the validity of the instruments in the Sargan OIR test. The numbers in parentheses are p-values. There is a difference between the total number of observations in the regression output and the total number of observations disclosed in the summary statistics is because of concerns about missing observations. The GMM strategy eliminates missing observations because lagged variables are used as instruments. (-1) stands for the lagged dependent variable. 


\subsection{Further discussion of results}

In this section we discuss the: (i) implications of the estimated coefficients, (ii) possible channels via which the mobile improves governance and (iii) theoretical contributions to the ICT-governance literature.

First, the following points are noteworthy on the interest of bundling governance indicators: The insignificant effect of the political governance index despite the statistical significance of its constituents implies that using the term 'political governance' interchangeably with 'voice and accountability' and political stability/no violence may be inappropriate when discussing linkages between the mobile phone and governance standards in SSA. The inference is that the generalisations that mobiles could be used to promote higher morals in broadly defined metrics of political governance are not acceptable unless they are substantiated with empirical research findings. Moreover, extreme caution must be taken when reforms to the general political environment is based on findings obtained from extrapolating its constituent indicators. Research aimed at explaining why the effect of mobile phones on the composite measure of political governance is unimportant whereas the influence on its basic components is noteworthy could be the objective of future work. The inconsistency of the economic governance model is driven primarily by the invalidity of the regulation quality model. Finally, the observation that the impact of mobiles on general governance is three times that on the institutional governance measure is not surprising. This is because the former combines three governance dynamics, namely: institutional, political and economic governances. It follows that general governance is fundamentally driven by institutional governance in the mobile-governance nexus. Given that corruption- control is a component of institutional governance, the evidence is broadly consistent with recent African institutional literature that has established corruption-control to be the most significant tool in fighting conflicts/crimes (Asongu \& Kodila-Tedika, 2016) and software piracy (Asongu \& Andrés, 2013). Nevertheless, the significant effect of mobiles on general governance in spite of its minor association with some of on its constituent elements is an indication that mobile phone usage by itself may not encourage the adoption of good governance ethics in all of its key dimensions. However, our findings show that a greater rate of diffusion of mobile phones enables good institutional governance practices, presumably by improving the design and implementation of the rule of law as well as the ability of the authorities to detect and punish corrupt behaviour. This latter perspective is consistent with Snow (2009, pp. 337-339). 
Second, we now turn our attention to the possible channels via which the mobile phone can reduce the monopoly of information with concomitant improvement in governance values. As observed by Hellstrom (2008) on corruption-control, there are five important reasons for the positive linkage between mobile phones and governance dynamics. They involve (i) better access to timely and accurate information, (ii) a speedy adoption of policies, (iii) increased participation of citizens in the design of institutions that govern them, (iv) improved interaction between institutions and government officials as well as between the authorities and their citizens and (v) a more realistic cost-benefit calculations for investments.

Third, while our findings are in line with theoretical underpinnings from Snow (2009), it is also important to discuss how our findings contribute to the mobile phone-governance literature, notably in terms of: convergence and information asymmetry.

Initially, we found from the GMM results that countries with lower levels of governance are catching-up their counterparts with higher governance values. This catch-up process is known as convergence. The findings have also contributed to the theoretical foundations of catch-up literature by extending the mainstream outcome variable from GDP per capita to other development indicators like governance. Indeed, the theoretical concepts of cross-country income catch-up that have been documented within the framework of neoclassical growth models (Solow, 1956; Swan, 1956; Baumol, 1986; Barro, 1991; Mankiw et al., 1992; Barro \& Sala-i-Martin, 1992, 1995; Fung, 2009) have recently been extended to other development fields: financial markets (Narayan et al., 2011; Bruno et al., 2012), knowledge economy (Asongu, 2017) and inclusive human development (Mayer-Foulkes, 2010).

Additionally, we reported that, mobile phones facilitate information sharing. Such helps to mitigate information asymmetry for better oversight by households, public officials and civil society. The fact that the mobile phone has been documented to be more positively correlated with the informal sector compared to the formal (Asongu, 2013) implies that a civil society that traditionally operates in the informal economic sector could also enhance the adoption of good governance practices by means of the mobile telephony. In a nutshell, the mobile phone helps to information asymmetry by ensuring that 'governance cost' is minimised and resources are allocated more efficiently. This is broadly supported by theories on information asymmetry in the banking sector documented by Claus and Grimes (2003).

As a caveat to the study, critics may maintain that our findings on the causal relationship between mobile phone usage and governance are doubtful. This is essentially 
because even with the GMM and the inclusion of control variables, the findings may not necessarily be causal. One reason for this shortcoming is that mobile phones could merely coincide with other antecedent factors with which its diffusion is highly correlated, namely: internet connectivity and social media. Given that our regression models do not explicitly control for social media and the internet and owing to their apparently high correlations with mobile phone penetration, we ran several falsification tests in order to assess whether other technological factors drive governance. For example, when mobile phone usage is replaced with internet penetration rate, the later significantly affects all dimensions of governance positively. We could not find comparative data on social media with the same periodicity, 2000-2012. We found Facebook penetration data only for the year 2012 and could not find Twitter penetration data. Hence, since internet penetration has been shown to significantly influence governance dynamics, the allegation of a causal linkage between mobile phones and good governance may be questionable. However, it is reasonable to propose that mobile phone usage has a positive relationship with governance ethics. This clarification and the confirmation of such a positive relationship in our empirical study are not inconsistent with the title of this study: "the mobile phone as an argument for good governance". Nonetheless, the term "argument" does not preclude a robust relationship, simply because causality cannot be unequivocally established.

\section{Concluding implications, caveats and future directions}

This study has presented theoretical and empirical arguments for the role of the mobile telephony in promoting good governance in 47 sub-Saharan African countries for the period 2000-2012. The empirical evidence is based on GMM with forward orthogonal deviations. After presenting theoretical frameworks, we have proceeded to discussing the empirical findings by first employing six individual governance indicators and then bundling these into composite indices to make our arguments more robust while at the same time increase the subtlety in our empirical analysis.

The following findings are established. First, with unbundled governance indicators, mobile phones consistently raised the various dimensions of governance by the same magnitude, with the exception of the measure of regulation quality where the effect is doubled, although the regression model was shown to be invalid. Second, when indicators are bundled, with the exclusions of political governance index for which the effect of mobile 
phone is not statistically significant and the economic governance model which is statistically inaccurate, corresponding influences on the other indices of governance are positive. Indeed, the estimated positive effect on general governance is three times higher than that on institutional governance index. It follows that general governance is fundamentally driven by institutional governance in the mobile-governance nexus. Third, countries with lower levels of governance dynamics are catching-up their counterparts with higher governance values. Three other points which were highlighted in the paper include: (i) its contribution to the theoretical literature on mobile phone-governance nexus, (ii) the importance of bundling individual governance indicators into various composites indices and (iii) the channels through which the mobile phone could potentially raise governance standards.

As a main caveat the number of observations described in the summary statistics is higher than those reported in the estimation output. In the regression analysis, the missing observations are automatically dropped by the econometrics software. Hence, we have no possibility of knowing which observations are dropped in order to align the number of observations provided in the summary statistics with those disclosed in the results output. This has been clarified in the caveat section.

Future studies within the scope of this inquiry would improve the extant literature by assessing how the diffusion of knowledge or other knowledge economy variables affect the established positive mobile-governance relationship. Reverse causality could also be a problem because Buys et al. (2009) have made the case that better governance practices also contribute to deeper mobile penetration in some markets. Moreover, explaining why the impact of mobile phones on political governance index is insignificant whereas the influence on constituent indicators is statistically significant could be the objective of future research. 


\section{Appendices}

Appendix 1: Definitions of variables

\begin{tabular}{|c|c|c|c|}
\hline Variables & Signs & Definitions of variables (Measurements) & Sources \\
\hline Political Stability & PolSta & $\begin{array}{l}\text { "Political stability/no violence (estimate): measured as the } \\
\text { perceptions of the likelihood that the government will be } \\
\text { destabilized or overthrown by unconstitutional and violent } \\
\text { means, including domestic violence and terrorism" }\end{array}$ & World Bank (WDI) \\
\hline $\begin{array}{l}\text { Voice \& } \\
\text { Accountability }\end{array}$ & $\mathrm{V} \& \mathrm{~A}$ & $\begin{array}{l}\text { "Voice and accountability (estimate): measures the extent to } \\
\text { which a country's citizens are able to participate in selecting } \\
\text { their government and to enjoy freedom of expression, } \\
\text { freedom of association and a free media". }\end{array}$ & World Bank (WDI) \\
\hline $\begin{array}{l}\text { Political } \\
\text { Governance }\end{array}$ & Polgov & $\begin{array}{l}\text { First Principal Component of Political Stability and Voice \& } \\
\text { Accountability. The process by which those in authority are } \\
\text { selected and replaced. }\end{array}$ & PCA \\
\hline $\begin{array}{l}\text { Government } \\
\text { Effectiveness }\end{array}$ & Gov. E & $\begin{array}{l}\text { "Government effectiveness (estimate): measures the quality } \\
\text { of public services, the quality and degree of independence } \\
\text { from political pressures of the civil service, the quality of } \\
\text { policy formulation and implementation, and the credibility of } \\
\text { governments' commitments to such policies". }\end{array}$ & World Bank (WDI) \\
\hline $\begin{array}{l}\text { Regulation } \\
\text { Quality }\end{array}$ & RQ & $\begin{array}{l}\text { "Regulation quality (estimate): measured as the ability of the } \\
\text { government to formulate and implement sound policies and } \\
\text { regulations that permit and promote private sector } \\
\text { development". }\end{array}$ & World Bank (WDI) \\
\hline $\begin{array}{l}\text { Economic } \\
\text { Governance }\end{array}$ & Econgov & $\begin{array}{l}\text { "First Principal Component of Government Effectiveness and } \\
\text { Regulation Quality. The capacity of government to formulate } \\
\text { \& implement policies, and to deliver services". }\end{array}$ & PCA \\
\hline Rule of Law & RL & $\begin{array}{l}\text { "Rule of law (estimate): captures perceptions of the extent to } \\
\text { which agents have confidence in and abide by the rules of } \\
\text { society and in particular the quality of contract enforcement, } \\
\text { property rights, the police, the courts, as well as the } \\
\text { likelihood of crime and violence". }\end{array}$ & World Bank (WDI) \\
\hline $\begin{array}{l}\text { Corruption- } \\
\text { Control }\end{array}$ & $\mathrm{CC}$ & $\begin{array}{l}\text { "Control of corruption (estimate): captures perceptions of the } \\
\text { extent to which public power is exercised for private gain, } \\
\text { including both petty and grand forms of corruption, as well as } \\
\text { 'capture' of the state by elites and private interests". }\end{array}$ & World Bank (WDI) \\
\hline $\begin{array}{l}\text { Institutional } \\
\text { Governance }\end{array}$ & Instgov & $\begin{array}{l}\text { First Principal Component of Rule of Law and Corruption- } \\
\text { Control. The respect for citizens and the state of institutions } \\
\text { that govern the interactions among them }\end{array}$ & PCA \\
\hline $\begin{array}{l}\text { General } \\
\text { Governance }\end{array}$ & G.gov & $\begin{array}{l}\text { First Principal Component of Political, Economic and } \\
\text { Institutional Governances }\end{array}$ & PCA \\
\hline Mobile phones & Mobile & Mobile phone subscriptions (per 100 people) & World Bank (WDI) \\
\hline GDP growth & GDPg & Gross Domestic Product (GDP) growth (annual \%) & World Bank (WDI) \\
\hline $\begin{array}{l}\text { Population } \\
\text { growth }\end{array}$ & Popg & Population growth rate (annual \%) & World Bank (WDI) \\
\hline $\begin{array}{l}\text { Foreign } \\
\text { investment }\end{array}$ & FDI & Foreign Direct Investment inflows (\% of GDP) & World Bank (WDI) \\
\hline Foreign aid & Aid & Total Development Assistance (\% of GDP) & World Bank (WDI) \\
\hline
\end{tabular}

Appendix 2: Summary statistics (2000-2012)

\begin{tabular}{llllll}
\hline Mean & SD & Minimum & Maximum & Observations \\
\hline
\end{tabular}




\begin{tabular}{|c|c|c|c|c|c|}
\hline Political Stability & -0.491 & 0.901 & -2.660 & 1.192 & 564 \\
\hline Voice \& Accountability & -0.617 & 0.721 & -2.175 & 0.990 & 564 \\
\hline Political Governance & 0.066 & 1.231 & -2.653 & 2.583 & 564 \\
\hline Government Effectiveness & -0.737 & 0.588 & -1.960 & 0.934 & 563 \\
\hline Regulation Quality & -0.676 & 0.599 & -2.260 & 0.983 & 564 \\
\hline Economic Governance & 0.084 & 1.278 & -2.886 & 3.808 & 563 \\
\hline Rule of Law & -0.704 & 0.624 & -2.113 & 1.056 & 564 \\
\hline Control of Corruption & -0.616 & 0.574 & -1.705 & 1.249 & 564 \\
\hline Institutional Governance & 0.070 & 1.302 & -2.391 & 3.766 & 564 \\
\hline General Governance & 0.130 & 2.078 & -4.567 & 5.561 & 563 \\
\hline Mobile phone penetration & 23.774 & 28.170 & 0.000 & 147.20 & 560 \\
\hline GDP growth & 4.807 & 5.973 & -32.832 & 63.380 & 604 \\
\hline Population growth & 2.327 & 0.920 & -1.081 & 6.576 & 564 \\
\hline Foreign Direct Investment inflows & 5.332 & 8.738 & -6.043 & 91.007 & 603 \\
\hline Foreign aid & 11.686 & 14.214 & -0.253 & 181.19 & 604 \\
\hline
\end{tabular}

\section{Appendix 3: Correlation matrix}

\begin{tabular}{|c|c|c|c|c|c|c|c|c|c|c|c|c|c|c|c|}
\hline \multirow{2}{*}{\multicolumn{3}{|c|}{ Political governance }} & \multicolumn{6}{|c|}{ Governance variables } & & & \multicolumn{3}{|c|}{ Control variables } & \multirow{3}{*}{$\begin{array}{l}\text { Mobile } \\
\text { Phones }\end{array}$} & \\
\hline & & & \multicolumn{3}{|c|}{ Economic governance } & \multicolumn{5}{|c|}{ Institutional governance } & \multirow[b]{2}{*}{ Popg } & \multirow[b]{2}{*}{ FDI } & \multirow[b]{2}{*}{ Aid } & & \\
\hline PS & VA & Polgov & GE & RQ & $\begin{array}{l}\text { Econgo } \\
\mathrm{V}\end{array}$ & $\mathrm{CC}$ & RL & Instgov & G.gov & GDPg & & & & & \\
\hline \multirow[t]{15}{*}{1.000} & 0.663 & 0.908 & 0.642 & 0.598 & 0.643 & 0.647 & 0.777 & 0.739 & 0.801 & -0.005 & -0.242 & -0.012 & -0.142 & 0.338 & PS \\
\hline & 1.000 & 0.915 & 0.767 & 0.759 & 0.791 & 0.682 & 0.813 & 0.776 & 0.874 & 0.047 & -0.209 & -0.023 & -0.029 & 0.304 & VA \\
\hline & & 1.000 & 0.774 & 0.745 & 0.788 & 0.729 & 0.872 & 0.831 & 0.919 & 0.023 & -0.247 & -0.019 & -0.093 & 0.351 & Polgov \\
\hline & & & 1.000 & 0.861 & 0.965 & 0.827 & 0.894 & 0.894 & 0.935 & 0.015 & -0.336 & -0.100 & -0.206 & 0.359 & GE \\
\hline & & & & 1.000 & 0.964 & 0.717 & 0.835 & 0.806 & 0.892 & 0.030 & -0.185 & -0.110 & -0.217 & 0.337 & RQ \\
\hline & & & & & 1.000 & 0.801 & 0.896 & 0.881 & 0.947 & 0.023 & -0.271 & -0.109 & -0.219 & 0.361 & Econgov \\
\hline & & & & & & 1.000 & 0.851 & 0.963 & 0.884 & -0.054 & -0.291 & -0.077 & -0.115 & 0.319 & $\mathrm{CC}$ \\
\hline & & & & & & & 1.000 & 0.961 & 0.966 & -0.001 & -0.254 & -0.064 & -0.148 & 0.346 & $\mathrm{RL}$ \\
\hline & & & & & & & & 1.000 & 0.961 & -0.029 & -0.284 & -0.074 & -0.137 & 0.346 & Instgov \\
\hline & & & & & & & & & 1.000 & 0.005 & -0.284 & -0.073 & -0.160 & 0.373 & G.gov \\
\hline & & & & & & & & & & 1.000 & 0.282 & 0.001 & 0.087 & -0.036 & GDPg \\
\hline & & & & & & & & & & & 1.000 & 0.077 & 0.363 & -0.341 & Popg \\
\hline & & & & & & & & & & & & 1.000 & 0.317 & 0.073 & FDI \\
\hline & & & & & & & & & & & & & 1.000 & -0.227 & Aid \\
\hline & & & & & & & & & & & & & & 1.000 & Mobile \\
\hline
\end{tabular}

PS: Political Stability/Non violence. VA: Voice \& Accountability. Polgov: Political Governance. GE: Government Effectiveness. RQ: Regulation Quality. Econgov: Economic Governance. CC: Corruption-Control. RL: Rule of Law. Instgov: Institutional Governance. G.Gov: General Governance. GDPg: GDP growth. Popg: Population growth. FDI: Foreign Direct Investment inflows. Aid: Foreign aid. Mobile: Mobile Phone penetration.

\section{Appendix 4: Persistence of the dependent variables}

\begin{tabular}{|c|c|c|c|c|c|c|c|c|c|c|}
\hline & \multicolumn{3}{|c|}{ Political Governance } & \multicolumn{3}{|c|}{ Economic Governance } & \multicolumn{3}{|c|}{ Institutional Governance } & \multirow[b]{2}{*}{ G.gov } \\
\hline & PS & VA & Polgov & GE & RQ & Ecogov & $\mathrm{CC}$ & RL & Instgov & \\
\hline PS(-1) & 0.965 & & & & & & & & & \\
\hline $\mathrm{VA}(-1)$ & & 0.982 & & & & & & & & \\
\hline Polgov(-1) & & & 0.981 & & & & & & & \\
\hline $\mathrm{GE}(-1)$ & & & & 0.979 & & & & & & \\
\hline $\mathrm{RQ}(-1)$ & & & & & 0.981 & & & & & \\
\hline Econgov(-1) & & & & & & 0.986 & & & & \\
\hline $\mathrm{CC}(-1)$ & & & & & & & 0.967 & & & \\
\hline $\mathrm{RL}(-1)$ & & & & & & & & 0.985 & & \\
\hline $\operatorname{Instgov}(-1)$ & & & & & & & & & 0.984 & \\
\hline G.gov(-1) & & & & & & & & & & 0.990 \\
\hline
\end{tabular}




\section{References}

Abor, J. Y., Amidu, Y., \& Issahaku, H., (2018). "Mobile Telephony, Financial Inclusion and Inclusive Growth", Journal of African Business, 18(4), pp. 430-453.

Afutu-Kotey, R. L., Gough, K. W., \& Owusu, G., (2017). "Young Entrepreneurs in the Mobile Telephony Sector in Ghana: From Necessities to Aspirations". Journal of African Business, 18(4), pp. 476-491.

Ajide, K. B, \& Raheem, I. D., (2016a). "Institutions-FDI Nexus in ECOWAS Countries", Journal of African Business, 17(3), pp. 319-341.

Ajide, K. B, \& Raheem, I. D., (2016b). “The Institutional Quality Impact on Remittances in the ECOWAS Sub-Region”, African Development Review, 28(4), pp. 462-481.

Andrés, R. A, \& Asongu, S. A., (2013). "Fighting Software Piracy: Which Governance Tools Matter in Africa?", Journal of Business Ethics, 118(3), pp. 667-682.

Andrés, R. A, Asongu, S. A., \& Amavilah, V. H., (2015). "The Impact of Formal Institutions on Knowledge Economy”, Journal of the Knowledge Economy, 6(4), pp. 1034-1062.

Anyanwu, J., \& Erhijakpor, A., (2014). "Does Oil Wealth Affect Democracy in Africa?"African Development Review, 26 (1), pp. 15-37.

Arellano, M., \& Bond, S., (1991), "Some tests of specification for panel data: Monte Carlo evidence and an application to employment equations" The Review of Economic Studies, 58(2), pp. 277-297.

Arellano, M., \& Bover, O., (1995), "Another look at the instrumental variable estimation of error components models", Journal of Econometrics, 68(1), pp. 29-52.

Asongu, S. A., (2013). "How has mobile phone penetration stimulated financial development in Africa", Journal of African Business, 14(1), pp. 7-18.

Asongu, S. A., (2014). “African development: beyond income convergence”, South African Journal of Economics, 83(3), pp. 334-353.

Asongu, S. A., (2018). "Conditional Determinants of Mobile Phones Penetration and Mobile Banking in Sub-Saharan Africa”, Journal of the Knowledge Economy, 9(1), pp. 81-135.

Asongu, S. A., (2016). "Determinants of Growth in Fast Developing Countries: Evidence from Bundling and Unbundling Institutions", Politics \& Policy, 44(1), pp. 97-134.

Asongu, S. A., (2017). "Knowledge Economy Gaps, Policy Syndromes and Catch-Up Strategies: Fresh South Korean Lessons to Africa", Journal of the Knowledge Economy, 8(1), pp. 211-253.

Asongu, S. A., \& Boateng, A., (2018). "Introduction to Special Issue: Mobile Technologies and Inclusive Development in Africa", Journal of African Business, 19(3), pp. 297-301. 
Asongu, S. A., \& De Moor, L., (2015). "Recent advances in finance for inclusive development: a survey", African Governance and Development Institute Working Paper No. 15/005, Yaoundé.

Asongu, S. A., \& De Moor, L., (2017). "Financial globalisation dynamic thresholds for financial development: evidence from Africa", The European Journal of Development Research, 29(1), pp. 192-212.

Asongu, S. A., \& Kodila-Tedika, O., (2017). “Is Poverty in the African DNA (Gene)?”, South African Journal of Economics. 85(4), pp. 533-552.

Asongu, S. A., \& Kodila-Tedika, O., (2016). "Fighting African Conflicts and Crimes: Which Governance Tools Matter?” International Journal of Social Economics, 43(5), pp. 466-485.

Asongu, S. A., \& le Roux, S., (2016). "Understanding Sub-Saharan Africa's Extreme Poverty Tragedy", International Journal of Public Administration.

DOI: 10.1080/01900692.2018.1466900.

Asongu, S. A., \& Nwachukwu, J., (2016a). "The Mobile Phone in the Diffusion of Knowledge for Institutional Quality in Sub-Saharan Africa", World Development, 86(October): pp. 133-147.

Asongu, S. A., \& Nwachukwu, J., (2016b). "Revolution empirics: predicting the Arab Spring” Empirical Economics, 51(2), pp. 439-482.

Asongu, S. A., \& Nwachukwu, J., (2016c). "Foreign aid and governance in Africa", International Review of Applied Economics, 30(1), pp. 69-88.

Asongu, S. A., \& Nwachukwu, J., (2017). "The Impact of Terrorism on Governance in African Countries”, World Development, 99(October), pp. 253-270.

Asongu, S. A., \& Ssozi, J., (2016). "Sino-African Relations: Some Solutions and Strategies to the Policy Syndromes", Journal of African Business, 17(1), pp. 33-51.

Asongu, S. A., Tchamyou, V. S, Asongu, N., \& Tchamyou, N., (2017). "The Comparative African Economics of Inclusive Development and Military Expenditure in Fighting Terrorism," Journal of African Development, 19(2), pp.77-91.

Ba, J., \& Ng S (2006). "Confidence intervals for diffusion index forecasts and inference for factor-augmented regression", Econometrica, 74(4), pp. 1133-1150.

Bai, J., (2003). "Inferential theory for factor models of large dimensions". Econometrica, 71 (1),pp.135-173.

Bai, J., (2009). "Panel data models with interactive fixed effects". Econometrica, 77(4), pp. 1229-1279.

Baltagi, B. H., (2008). "Forecasting with panel data", Journal of Forecasting, 27(2), pp. 153173. 
Barro, R., (1991). "Economic Growth in a Cross Section of Countries". Quarterly Journal of Economics 196, (2/May), pp. 407-443.

Barro, R. J., \& Sala-i-Martin, X., (1992). “Convergence”, Journal of Political Economy, 100(2), pp. 223-251.

Barro, R. J., \& Sala-i-Martin, X., (1995). Economic Growth. The MIT Press, Cambridge, MA.

Baumol, W. J., (1986). "Productivity, growth, convergence and welfare: what the long run data show", American Economic Review, 76(5), pp. 1072-1085.

Bicaba, Z., Brixiová, Z., \& Ncube, M., (2017). "Can Extreme Poverty in Sub-Saharan Africa be Eliminated by 2030?," Journal of African Development, 19(2), pp. 93-110.

Blundell, R., \& Bond, S., (1998). "Initial conditions and moment restrictions in dynamic panel data models", Journal of Econometrics, 87(1), pp. 115-143.

Boateng, A., Asongu, S. A., Akamavi, R., \& Tchamyou, V. S., (2018). "Information Asymmetry and Market Power in the African Banking Industry", Journal of Multinational Financial Management, 44(March), pp. 69-83.

Bond, S., Hoeffler, A., \& Tample, J. (2001) “GMM Estimation of Empirical Growth Models", University of Oxford.

Bongomin, G. O. C., Ntayi, J. M., Munene J. C., \& Malinga, C. A., (2018). "Mobile Money and Financial Inclusion in Sub-Saharan Africa: the Moderating Role of Social Networks", Journal of African Business, 18(4), pp. 361-384.

Boulianne, S., (2009). "Does Internet Use Affect Engagement? A Meta-Analysis of Research", Political Communication, 26(2), pp. 193-211.

Breuer, A., Landmann, T., \& Farquhar, D., (2012). "Social media and protest mobilization: evidence from the Tunisian revolution", Democratization, 22(4), pp. 764-792.

Buys, P., Dasgupta, S., Thomas, T.S. \& Wheeler, D., (2009). "Determinants of a digital divide in sub-Saharan Africa: A spatial econometric analysis of cell phone coverage" World Development, 37 (9), pp. 149-1505.

Claus, I., \& Grimes, A., (2003). "Asymmetric Information, Financial Intermediation and the Monetary Transmission Mechanism: A Critical Review", NZ Treasury Working Paper No. 13/019, Wellington.

Costantini, M., \& Lupi, C., (2005). "Stochastic Convergence among European Economies". Economics Bulletin, 3(38), pp.1-17.

Dewan, S., \& Ramaprasad, J., (2014). "Social media, traditional media and music sales", MIS Quarterly, 38(1), pp. 101-128.

Diamond, L., (2010). “Liberation Technology”, Journal of Democracy, 21(3), pp. 69-83. 
Dixit, A., (2009). "Governance Institutions and Economic Activity", American Economic Review, 99(1), pp. 5-24.

Efobi, U., (2015). "Politicians' Attributes and Institutional Quality in Africa: A Focus on Corruption", Journal of Economic Issues, 49(3), pp. 787-813.

Fonchingong, C., (2014). "Firming Up Institutional Policy for Deprived Elderly in Cameroon", Politics \& Policy, 42(6), pp. 948-980.

Fosu, A., (2013a), "Growth of African Economies: Productivity, Policy Syndromes and the Importance of Institutions” Journal of African Economies, 22(4), pp. 523-551.

Fosu, A., (2013b). "Growth of African Economies: Productivity, Policy Syndromes and the Importance of Institutions" Journal of African Economies 22(4), pp. 523-551.

Fosu, A. K., (2015a). "Growth, Inequality and Poverty in Sub-Saharan Africa: Recent Progress in a Global Context”, Oxford Development Studies, 43(1), pp. 44-59.

Fosu, A., (2015b). Growth and Institutions in African Development, First edited by Augustin K. Fosu, , Routledge Studies in Development Economics: New York

Fosu, A., (2015c). Growth and institutions in African Development, in Growth and Institutions in African Development, First edited by Augustin K. Fosu, 2015, Chapter 1, pp. 1-17, Routledge Studies in Development Economics: New York.

Fukuyama, F., (2013). “What is Governance?”, Governance, 26(3), pp. 347-368.

Fung, M. K., (2009). "Financial development and economic growth: convergence or divergence?". Journal of International Money and Finance, 28(1), pp.56-67.

Gagliardone, I., (2016). “'Can you hear me?' Mobile-radio interactions and governance in Africa”, new media and society, 18 (9), pp. 2080-2095

Gani, A., (2011). "Governance and Growth in Developing Countries", Journal of Economic Issues, 45(1), pp. 19-40.

Gosavi, A., (2018). "Can Mobile Money Help Firms Mitigate the Problem of Access to Finance in Eastern sub-Saharan Africa”, Journal of African Business, 18(4), pp. 343-360.

Greenaway-McGrevy, R., Han, C., \& Sul, D., (2012). “Asymptotic distribution of factor augmented estimators for panel regression”. Journal of Econometrics, 169 (1), pp. 48-53.

Grossman, G., Humphreys, M., and Sacramone-Lutz, G., (2014). ““'I wld like u WMP to extend electricity 2 our village": On Information Technology and Interest Articulation", American Political Science Review, 108(3), pp. 688-705.

Hellstrom, J. (2008), "Mobile phones for good governance- challenges and way forward", Stockholm University / UPGRAID, http://www.w3.org/2008/10/MW4D_WS/papers/hellstrom_gov.pdf (Accessed: 22/11/2015). 
Hubani, M., \& Wiese, M., (2018). "A Cashless Society for All: Determining Consumers' Readiness to Adopt Mobile Payment Services", Journal of African Business, 18(4), pp. 409429.

Issahaku, H., Abu, B. M., \& Nkegbe, P. K., (2018). "Does the Use of Mobile Phones by Smallholder Maize Farmers Affect Productivity in Ghana?", Journal of African Business, 19(3), pp. 302-322.

Jolliffe, I. T. (2002) Principal Component Analysis (2nd Ed.) New York: Springer.

Kaiser, H. F. (1974) “An index of factorial simplicity” Psychometrika 39(1), pp. 31-36.

Kaufmann, D., Kraay, A., \& Mastruzzi, M., (2007a). "Growth and Governance: A Reply", Journal of Politics, 69(2), pp. 555-562.

Kaufmann, D., Kraay, A., \& Mastruzzi, M., (2007b). "Growth and Governance: A Rejoinder”, Journal of Politics, 69(2), pp. 570-572.

Kaufmann, D., Kraay, A \& Mastruzzi, M., (2010). "The worldwide governance indicators: Methodology and analytical Issues". World Bank Policy Research Working Paper No 5430, Washington.

Kurtz, M., \& Schrank, A., (2007a). "Growth and Governance: Models, Measures, and Mechanisms", Journal of Politics, 69(2), pp. 538-554.

Kurtz, M., \& Schrank, A., (2007b). "Growth and Governance: A Defense", Journal of Politics, 69(2), pp. 563-569.

Kuada, J., (2009). "Gender, social networks, and entrepreneurship in Ghana", Journal of African Business, 10 (1), pp. 85-103.

Kuada, J. (2014). "Cross- border interfirm knowledge generation and enterprise development in Africa", in Nwankwo, S. and Ibeh, K. (Eds), The Routledge Companion to Business in Africa, Routledge, London and New York, pp. 352-370.

Kuada, J., (2015). "Entrepreneurship in Africa - a classificatory framework and a research Agenda", African Journal of Economic and Management Studies, 6(2), pp. 148-163.

Lalountas, D. A., Manolas, G.A., \& Vavouras, I.S., (2011), “Corruption, globalization and development: How are these three phenomena related?", Journal of Policy Modeling, 33(4), pp. 636-648.

Love, I., \& Zicchino, L., (2006). "Financial Development and Dynamic Investment Behaviour: Evidence from Panel VAR" .The Quarterly Review of Economics and Finance, 46(2), pp. 190-210.

Manacorda, M., \& Tesei, A., (2016). "Liberation Technology: Mobile Phones and Political Mobilization in Africa", Queen Mary University of London, 
http://personal.lse.ac.uk/manacorm/liberation_technology.pdf (Accessed: 20/02/2016).

Mankiw, N. G., Romer, D., \& Weil, D. N., (1992). "A contribution to the empirics of economic growth", Quarterly Journal of Economics, 107(2), pp. 407-437.

Matthias, M., (2012). "Connectivity and Accountability in Africa", The Futurist, 46(1), pp. 67.

Muthinja, M. M., \& Chipeta, C., (2018). "What Drives Financial Innovations in Kenya's Commercial Banks? An Empirical Study on Firm and Macro-Level Drivers of Branchless Banking", Journal of African Business, 18(4), pp. 385-408.

Mayer-Foulkes, D., (2010). "Divergences and Convergences in Human Development". UNDP Human Development Research Paper 2010/20, New York.

Minkoua Nzie, J. R., Bidogeza, J. C., \& Ngum, N. A., (2018). "Mobile Phone Use, Transaction Costs, and Price: Evidence from Rural Vegetable Farmers in Cameroon", Journal of African Business, 19(3), pp. 323-342.

Morozov, E., (2011), The Net Delusion: How Not to Liberate The World. London: Penguin Books.

McKenzie C, R., \& McAleer M (1997). "On efficient estimation and correct inference in models with generated regressors: A general approach.” Japanese Economic Review, 48(4), pp. 368-389.

Mpogole, H., Usanga, H., \& Tedre, M., (2008). "Mobile phones and poverty alleviation: a survey study in rural Tanzania", Proceedings of M4D 2008, Karlstad University, Sweden, pp. $62-72$.

Narayan, P.K., Mishra, S., \& Narayan, S., (2011). "Do market capitalization and stocks traded converge? New global evidence". Journal of Banking and Finance, 35(10), pp.2771-2781.

Okada, K., \& Samreth, S.,(2012), "The effect of foreign aid on corruption: A quantile regression approach", Economic Letters, 11(2), pp. 240-243.

Oluwatobi, S., Efobi, U.R., Olurinola, O.I., Alege, P. (2015), "Innovation in Africa: Why Institutions Matter", South African Journal of Economics, 83(3), pp. 390-410.

Oxley L, \& McAleer, M., (1993). "Econometric issues in macroeconomic models with generated regressors." Journal of Economic Surveys, 7(1), pp. 1-40.

Pagan, A., (1984). "Econometric issues in the analysis of regressions with generated regressors", International Economic Review, 25(1), pp. 221-247. 
Penard, T., Poussing, N., Yebe, G. Z., \& Ella, P. N., (2012). "Comparing the Determinants of Internet and Cell Phone Use in Africa: Evidence from Gabon ", Communications \& Strategies, 86(2), pp. 65-83.

Pesaran, M. H., (2006). "Estimation and inference in large heterogeneous panels with a multifactor error structure". Econometrica 74 (4), pp. 967-1012.

Pierskalla, J. H., \& Hollenbach, F. M., (2013). "Technology and Collective Action: The Effect of Cell Phone Coverage on Political Violence in Africa", American Political Science Review, 107(2), pp. 207-224.

Porter, G., Hampshire, K., Milner, J., Munthali, A., Robson, E., De Lannoy, A., Bango, A., Gunguluza, N., Mashiri, M., Tanle, A., and Abane, A., (2016). "Mobile Phones and Education in Sub-Saharan Africa: From Youth Practice to Public Policy", Journal of International Development, 28(1), pp. 22-39.

Roodman, D., (2009a). "A Note on the Theme of Too Many Instruments", Oxford Bulletin of Economics and Statistics, 71(1), pp. 135-158.

Roodman, D., (2009b). "How to do xtabond2: An introduction to difference and system GMM in Stata", Stata Journal, 9(1), pp. 86-136.

Snow, B. C., (2009). "Mobile Phone Diffusion and Corruption in Africa", Political Communication, 26(3), pp.333-353.

Solow, R. M., (1956). "A contribution to the theory of economic growth", Quarterly Journal of Economics, 70(1), pp. 65-94.

Stock, J. H. \& M. W. Watson (2002). "Forecasting using principal components from a large number of predictors". Journal of the American Statistical Association, 97 (460), pp.11671179.

Suarez, S. L., (2006). "Mobile democracy: text messages, voter turnout and the 2004 Spanish general election", Representation, 42(2), pp. 117-128.

Swan, T., (1956). "Economic growth and capital accumulation". Economic Record, 32(2), pp. 334-361.

Tchamyou, V. S., (2017). "The role of knowledge economy in African business", Journal of the Knowledge Economy, 8(4), pp. 1189-1228.

Tchamyou, V. S., Erreygers, G.,Cassimon, D.,(2018). "Inequality, ICT and Financial Access in Africa", Faculty of Applied Economics, University of Antwerp, Antwerp. Unpublished $\mathrm{PhD}$ Thesis Chapter.

Tchamyou, V. S., (2018a). "The role of Information sharing in modulating the effect of financial access on inequality". Journal of African Business: Forthcoming. 
Tchamyou, V. S., (2018b). "Education, Lifelong learning, Inequality and Financial access: Evidence from African countries", Contemporary Social Science.

DOI: $10.1080 / 21582041.2018 .1433314$.

Tchamyou, V. S, \& Asongu, S. A., (2017). "Information Sharing and Financial Sector Development in Africa". Journal of African Business, 18(1), pp. 24-49.

Tony, F. L., \& Kwan, D. S., (2015). “African Entrepreneurs and International Coordination in Petty Businesses: The Case of Low-End Mobile Phones Sourcing in Hong Kong”. Journal of African Business, 15(1-2), pp. 66-83.

Tusalem, R. F., (2015), "State Regulation of Religion and the Quality of Governance", Politics \& Policy, 43(1), pp. 94-141.

Weidmann, J. N., \& Shapiro, N. B., (2015). "Is the Phone Mightier Than the Sword? Cell phones and Insurgent Violence in Iraq", International Organisation, 69(2), pp. 247-274.

Westerlund, J., \& Urbain, J-P., (2013a). "On the estimation and inference in factor-augmented panel regressions with correlated loadings", Economic Letters, 119(3), pp. 247-250.

Westerlund, J., \& Urbain, J-P., (2013b). "On the implementation and use of factor-augmented regressions in panel data”, Journal of Asian Economics, 28 ( C ), pp. 3-11.

Westerlund, J., \& Urbain, J-P., (2012). “Cross-sectional averages versus principal components", Maastricht University, RM/11/053, Maastricht.

World Bank (2015). "World Development Indicators", World Bank Publications http://www.gopa.de/fr/news/world-bank-release-world-development-indicators-2015

(Accessed: 25/04/2015).

Yerrabati, S., \& Hawkes, D., (2015). "Economic Governance and Economic Growth in South and East Asia \& Pacific Region: Evidence from Systematic Literature Reviews and Metaanalysis". Advances in Economics and Business, 3(1), pp. 1 - 21. 